\title{
Direct Dates and mtDNA of Late Pleistocene Human Skeletons from South America: A Comment on Chatters et al. (2014)
}

\section{Donald Jackson, César Méndez, Michelle de Saint Pierre, and Eugenio Aspillaga}

Universidad de Chile, Santiago, Chile

\section{Gustavo G. Politis}

Universidad Nacional del Centro de la Provincia de Buenos Aires, Olavarría, Argentina Universidad de la Plata, Argentina

In a recent paper in the journal Science (2014, Vol. 344, pp. 750-754), J. Chatters et al. present a new early human skeleton from the Yucatan, Mexico, considering it in the context of eight other early "Paleoamerican" individuals-all from North America-that previously yielded ancient genetic evidence and/or direct radiocarbon ages. Despite including the archaeological site of Monte Verde II, Chile, in their discussion, we were alarmed that the authors otherwise ignored the South American record, presenting a map with the southern continent being devoid of PaleoAmerican human remains. We felt it important to remind our colleagues that South America has produced numerous directly dated human skeletal remains that are as old as the ones cited by Chatters et al. for North America, and that several of these have actually yielded mitochondrial (mt) DNA. Significant implications can be derived from this radiocarbon, bioanthropological, and mtDNA dataset, especially considering the antiquity of the earliest human populations and process of peopling of the New World.

Undoubtedly, the remains recovered from Hoyo Negro (HN5/48) cave by Chatters et al. constitute a significant archaeological discovery, considering how elusive and incomplete early skeletal material for the Americas is. The remains were recovered from an ancient cavern that was available to humans before the end of the Pleistocene, before Postglacial sealevel rise. Fresh bone fractures on the individual suggest a death due to a fall when the cavern was

Correspondence to: César Méndez, Ignacio Carrera Pinto 1045, Santiago, Chile. Email: cmendezm@uchile.cl. filled with shallow water. Consequently, the Hoyo Negro human skeleton represents a bone assemblage deposited naturally, in a palimpsest with remains of other species that accumulated at different times. As the authors discuss, radiocarbon and uranium-thorium dates on human teeth and bones, extinct faunal remains, and calcite speleothems together indicate the human remains were deposited by $12,000-13,000$ cal yr BP. However, the absence of associated cultural remains limits the interpretive value of this significant discovery.

Other skeletal remains have been recovered in a nearby flooded cave system known as Cenote Naharon, by a team led by A. González. Among them is a human femur radiocarbon dated to about 13,500 cal yr BP according to its amino-acid fraction, but this date has yet to be replicated, underscoring the problematic nature of dating organic material in these submerged cavern systems.

In South America, there are now 23 direct dates on 21 individuals from 13 sites that have yielded ages older than 10,000 cal yr BP (Table 1, Figure 1; for references see "Suggested Reading" after the editorial, as well as the report by L. Menendez et al. in this issue of PaleoAmerica). Among them, four sites have produced direct dates older than 12,000 cal yr BP: Los Rieles in the semiarid north of Chile, Arroyo de Frías in the Pampean region of Argentina, Gruta de Candonga in the Sierra de Córdoba of Argentina, and Toca do Gordo do Garrincho in northeastern Brazil.

Los Rieles is a shell midden located upon a high marine terrace where several human burials were excavated by D. Jackson, C. Méndez, and E. Aspillaga. 
Table 1

Directly dated South American skeletal material, $>10,000$ cal yr BP*

\begin{tabular}{|c|c|c|c|c|c|}
\hline Site, context & Lab number & $\begin{array}{l}\text { Chemical fraction } \\
\text { dated }\end{array}$ & Skeletal element & $\begin{array}{l}\text { Conventional age }\left({ }^{14} \mathrm{C}\right. \\
\text { yr BP })\end{array}$ & $\begin{array}{l}\text { Calibrated age } \\
\text { (cal yr BP; } 2 \sigma \text { ) }\end{array}$ \\
\hline Los Rieles, individual 1 & Beta-251901 & Collagen & Tooth & $10,470 \pm 60$ & $12,040-12,550$ \\
\hline Los Rieles, individual 1 & UGAMS-04599 & Collagen & Tooth & $10,150 \pm 30$ & $11,410-11,960$ \\
\hline Los Rieles, individual 1 & UCIAMS-79662 & Purified collagen & Petrosal & $9815 \pm 30$ & $11,160-11,250$ \\
\hline Cueva de Candonga & SRLA-1062 & Collagen & Skull & $10,450 \pm 50$ & $12,030-12,510$ \\
\hline Arroyo de Frías & CAMS-16598 & $\begin{array}{l}\text { XAD-KOH gelatin } \\
\text { hydrolyzate }\end{array}$ & Phalange & $10,300 \pm 60$ & $11,720-12,390$ \\
\hline Arroyo de Frías & OxA-8545 & Purified gelatin & $\begin{array}{l}\text { Phalange, right } \\
\text { hand }\end{array}$ & $9520 \pm 75$ & $10,520-11,100$ \\
\hline $\begin{array}{l}\text { Toca do Gordo do } \\
\text { Garrincho }\end{array}$ & Beta-136204 & - & Teeth & $12,210 \pm 40$ & $13,860-14,200$ \\
\hline Baño Nuevo 1, individual 1 & CAMS-79933 & Collagen & Bone & $8950 \pm 50$ & $9790-10,200$ \\
\hline Baño Nuevo 1, individual 3 & CAMS-101893 & Collagen & Bone & $8950 \pm 60$ & $9780-10,210$ \\
\hline Baño Nuevo 1, individual 4 & CAMS-101894 & Collagen & Bone & $8945 \pm 40$ & $9800-10,200$ \\
\hline Baño Nuevo 1, individual 5 & UCIAMS-10098 & Collagen & Bone & $8990 \pm 30$ & $9740-10,160$ \\
\hline Baño Nuevo 1, individual 7 & UGAMS-5927 & Collagen & Bone & $9020 \pm 30$ & $9930-10,230$ \\
\hline Baño Nuevo 1, individual 10 & UGAMS-5002 & Collagen & Tooth & $8960 \pm 40$ & $9900-10,200$ \\
\hline Acha 2 & KE-15082 & - & Muscle & $8970 \pm 255$ & $9460-10,700$ \\
\hline Hakenasa & Beta-187535 & Collagen & Bone & $9580 \pm 40$ & $10,700-11,090$ \\
\hline La Fundición 1 & UGAMS-8095 & Collagen & Bone & $9130 \pm 40$ & $10,180-10,380$ \\
\hline Piuquenes & Beta-151285 & Collagen & Bone & $9150 \pm 40$ & $10,200-10,400$ \\
\hline La Patagüilla & Beta-146493 & Collagen & Bone & $9550 \pm 110$ & $10,520-11,170$ \\
\hline La Patagüilla & Beta-146493 & Collagen & Bone & $9750 \pm 150$ & $10,590-11,600$ \\
\hline La Patagüilla & Beta-241961 & Collagen & Bone & $9800 \pm 50$ & $10,890-11,260$ \\
\hline Lapa Vermelha IV & Beta-84439 & - & Bone & $9370 \pm 60$ & $10,300-10,700$ \\
\hline Lapa do Braga & Beta-174736 & - & Bone & $9780 \pm 70$ & $10,790-11,270$ \\
\hline Laguna de Los Pampas & AA-90127 & Purified gelatin & Tooth & $8971 \pm 77$ & $9750-10,230$ \\
\hline
\end{tabular}

*Data taken from Bueno et al. (2013), Méndez (2013), and Prates et al. (2013); with references therein (see "Suggested Reading" at end of paper).

Among them is a flexed lateral primary burial intentionally covered with shells. These remains represent a well-preserved, nearly complete 40-45-year-old male displaying parafunctional wear on the teeth. Stable-isotope analyses $\left({ }^{15} \mathrm{~N}\right)$ indicate protein was predominantly obtained from marine foods, in agreement with regional evidence for the presence of a well-developed coastal adaptation during the early Holocene. Three AMS radiocarbon dates on collagen of two teeth and the petrosal bone were performed independently at different laboratories. Despite being statistically different at the $95 \%$ confidence level, they all predate $11,200 \mathrm{cal}$ yr BP. In this context, we cannot rule out slightly younger dates because of an undetermined reservoir effect caused by marine resource consumption.

The Arroyo de Frías remains, from the Pampas region, constitute skeletal remains of two individuals that F. Ameghino recovered between 1870 and 1874, at a reported depth of $2.5 \mathrm{~m}$ below the modern surface. Though some data are contradictory, it is plausible that the human remains were associated with archaeological material, including bones of extant and extinct mammal species. G. Politis and others have reanalyzed these materials and AMS radiocarbon dated two hand phalanges to 12,100 and 10,900 cal yr BP.

Cueva de Candonga is a cave site in the Sierras de Córdoba, Argentina, excavated in 1943 by A. Castellanos. In the cave a skeleton of a child was recovered, allegedly in association with bone instruments, parts of a hearth, and the bones of 13 animal taxa, including some extinct species. New studies by S. Cornero and her team have provided a new AMS radiocarbon age of 12,300 cal yr BP from a sample of the skull.

Finally, at Toca do Gordo do Garrincho, in northeastern Brazil, N. Guidón excavated human remains in a cave under a stalagmite dated to $11,000 \mathrm{cal}$ yr BP. One sample yielded an age of 14,000 cal yr BP, but it was performed on carbon recovered from acid washes of a combined sample of two human teeth recovered from different excavation levels. Considering this, the early age should be regarded with extreme caution.

Thus, the results from Los Rieles, Arroyo de Frías, and Cueva de Candonga include direct measurements on collagen of at least 11,200 cal yr BP, and thus are more secure than the enamel bioapatite dates for Hoyo Negro. The discrepancies in the dates obtained at Los Rieles and Arroyo de Frías sites are not due to contamination or diagenetic processes, but rather differences in purification methods. Other sites with radiocarbon ages between 12,000 and $10,000 \mathrm{cal} \mathrm{yr}$ BP have an even wider distribution in South America. Besides isolated human remains, among them are a high number of burials, such as those located in Laguna de los Pampas (with a minimum number of individuals (MNI) of 10) in the Pampean region, and Baño Nuevo $1(\mathrm{MNI}=10)$, in west-central Patagonia. 

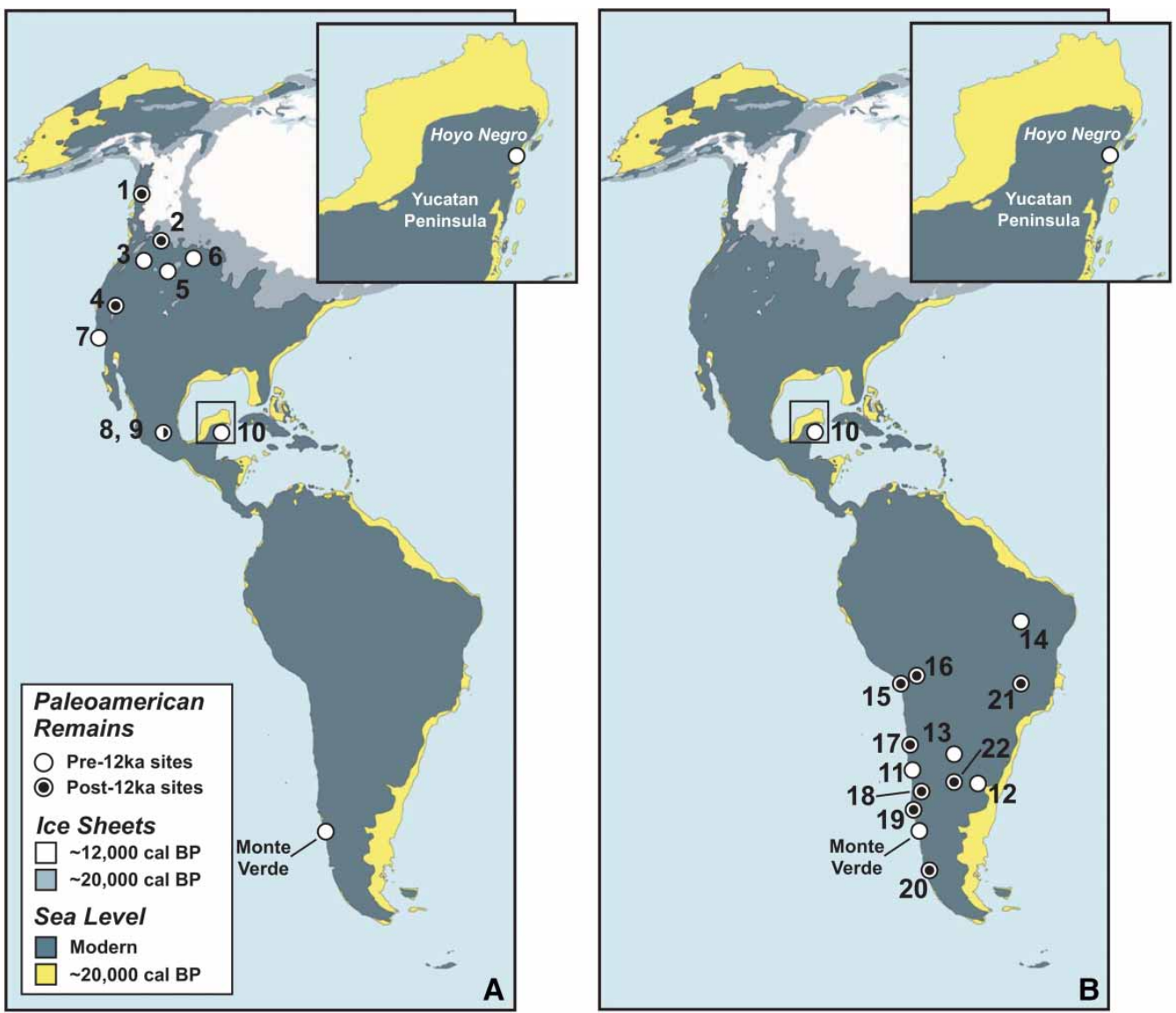

Figure 1 Maps of the Americas depicting sites with early dated bioarchaeological material. (A) North/Meso-American sites (after Chatters et al. 2014): (1) On Your Knees Cave, (2) Kennewick Man, (3) Paisley Caves, (4) Wizard's Beach, (5) Buhl, (6) Anzick, (7) Arlington Springs, (8) Peñón III, (9) Tlapacoya, and (10) Hoyo Negro. (B) South American sites with dates earlier than 10,000 cal yr BP: (11) Los Rieles, (12) Arroyo de Frías, (13) Cueva de Candonga, (14) Toca do Gordo do Garrincho, (15) Acha 2, (16) Hakenasa, (17) La Fundición 1, (18) Piuquenes, (19) La Patagüilla, (20) Baño Nuevo 1, (21) Lapa Vermelha IV and Lapa do Braga, and (22) Laguna de Los Pampas.

Although genetic material from human remains dating to the Pleistocene/Holocene transition has proven elusive, and genomic analyses of nuclear DNA have not yet been reported, initial mtDNA results present interesting patterns. Besides $\mathrm{HN} 5 / 48$ yielding the D1 haplogroup, samples from Anzick 1 (12,600 cal yr BP) and On Your Knees Cave (10,400 cal yr BP) both have yielded the D4h3a haplogroup, and Wizard's Beach $(10,400$ cal yr BP) has yielded the $\mathrm{Cl}$ haplogroup. For South America, the early genetic record is even more limited. O. Reyes et al. have reported that haplogroups $\mathrm{B}(n=5)$ and $\mathrm{C}(n=1)$ are present at Baño Nuevo 1, with skeletal material yielding eight direct AMS radiocarbon dates ranging from 10,100 to $9900 \mathrm{cal} \mathrm{yr} \mathrm{BP}$. The presence of the B haplogroup at this latitude $\left(45^{\circ} 30^{\prime} \mathrm{S}\right)$ is particularly interesting because studies of the last surviving native peoples of southernmost Patagonia (the Yámana, Kawésqar, Aonikenk, and Selk'nam) show a complete absence of this lineage, according to the recent work of M. de Saint Pierre and colleagues. The southernmost cases of the B2 haplogroup in Patagonia belong to the Tehuelche $(21 \%)$ at $42^{\circ} \mathrm{S}$ latitude, which include the B2i2 subhaplogroup only found among southern Chilean and northern Patagonian populations like the Mapuche, Pehuenche, and Huilliche. Thus the Baño Nuevo 1 remains can be considered as the likely candidate for the origin of the northern Patagonia B2i2 clade, not another foreign population, despite the lack of the B2 haplogroup in current populations beyond $45^{\circ} \mathrm{S}$.

Interestingly, the haplogroups represented in the North American samples connect them more strongly to South American extant native populations than to North American ones. Regarding the D1/Hoyo Negro link to southern South American populations mentioned by Chatters et al. in their recent paper, we should add the individuals from Anzick-1 and On Your Knees Cave as evidence for connections between northern Paleoamericans and Patagonian populations. The haplogroup D4h3a shared by the above-mentioned remains is today a very rare haplogroup, with frequencies less than $\sim 2 \%$ on the continent. Remarkably, however, D4h3a has been described in $25 \%$ of southern Patagonian native populations, and among them is the specific clade D4h3a5. 
Additionally, two mtDNA monophyletic subhaplogroups restricted to extant Patagonian populations, a D1 haplogroup named D1g and the above-mentioned B2i2, support the hypothesis of continuity from the initial founders to the current Patagonian populations, as de Saint Pierre and colleagues have proposed. The very old age estimated for these mtDNA clades (about $\sim 15,000$ cal yr BP) indicates they should have appeared soon after the arrival of the first settlers to the area. The geographic isolation of the region may have favored the retention of ancestral characters in Patagonian natives, thus accounting for the link between northern Paleoamericans with southern South America's current populations.

Combining direct radiocarbon information with genetic data from human remains is the most straightforward way to assess the dispersal of specific populations as they colonized new lands. Equivalently pondering data from different parts of the Americas is crucial for a thorough understanding of the early peopling process. Though being at the last corner of the continent, the growing body of South American bioarchaeological material is increasingly shedding light on the process of initial occupation of the hemisphere. We insist on the importance of performing state of the art analyses (i.e., radiocarbon, stableisotope, and genomic) on new discoveries and museum collections because a great deal of significant scientific information is potentially concealed within them.

\section{Suggested Reading}

Bueno, L., A. Schmidt Dias, and J. Steele. 2013. "The late Pleistocene/early Holocene archaeological record in Brazil: A geo-referenced database." Quaternary International 301: 74-93.
Chatters, J. C., D. J. Kennett, Y. Asmerom, B. M. Kemp, V. Polyak, A. Nava Blank, P. A. Beddows, E. Reinhardt, J. ArroyoCabrales, D. A. Bolnick, R. S. Malhi, B. J. Culleton, P. L. Erreguerena, D. Rissolo, S. Morell-Hart, and T. W. Stafford, Jr. 2014. "Late Pleistocene human skeleton and mtDNA link Paleoamericans and modern Native Americans." Science 344: $750-754$.

Cornero, S., W. Neves, and D. Rivero. 2014. "Nuevos aportes a la cronología de las ocupaciones tempranas en las Sierras de Córdoba. La Gruta de Candonga (Córdoba, Argentina)." Relaciones de la Sociedad Argentina de Antropología: XXXIX(1): 285-292.

de Saint Pierre, M., C. M. Bravi, J. M. B. Motti, N. Fuku, M. Tanaka, E. Llop, S. L. Bonatto, and M. Moraga. 2012. "An alternative model for the early peopling of southern South America revealed by analyses of three mitochondrial DNA haplogroups." PLoS One 7: e43486.

González González, A. H., C. Rojas Sandoval, A. Terrazas Mata, M. Benavente Sanvicente, W. Stinnesbeck, J. Avilés O., M. de los Ríos, and E. Acevez. 2008. "The arrival of humans on the Yucatan Peninsula: Evidence from submerged caves in the state of Quintana Roo, Mexico." Current Research in the Pleistocene 25: 1-24.

Guidon, N., E. Peyre, C. Guerin, and Y. Coppens. 2000. "Resultados da datação de dentes humanos da Toca do Garrincho, Piauí-Brasil." CLIO (Revista do Programa de Pós-Graduação em História da Universidade Federal de Pernambuco-Série Arqueológica) 14: 75-86.

Jackson, D., C. Méndez, and E. Aspillaga. 2012. "Human remains directly dated to the Pleistocene-Holocene transition support a marine diet for early settlers of the Pacific coast of Chile." Journal of Island \& Coastal Archaeology 7: 363-377.

Méndez, C. 2013. "Terminal Pleistocene/early Holocene ${ }^{14} \mathrm{C}$ dates from archaeological sites in Chile: Critical chronological issues for the initial peopling of the region." Quaternary International 301: 60-73.

Politis, G., G. Barrientos, and T. W. Stafford. 2011. "Revisiting Ameghino: New ${ }^{14} \mathrm{C}$ dates from human ancient skeletons from the Argentine Pampas." In Peuplements et Préhistoire en Amériques, edited by D. Vialou, 3-53. Paris: Editions du Comité des Travaux Historiques et Scientifique.

Prates, L., G. Politis, and J. Steele. 2013. "Radiocarbon chronology of the early human occupation of Argentina." Quaternary International 301: 104-122.

Reyes, O., C. Méndez, F. Mena, and M. Moraga. 2012. "The bioanthropological evidence of a ca. 10,000 CALYBP ten-individual group in central Patagonia." In Southbound: Late Pleistocene Peopling of Latin America, edited by L. Miotti, M. Salemme, N. Flegenheimer, and T. Goebel, 39-43. College Station: Center for the Study of the First Americans.

\section{Author's Biographies}

Donald Jackson is professor of Anthropology at Universidad de Chile. His field-based archaeological research program, FONDECYT 1140824, is focused on the study of the early peopling of the Semiarid north of Chile.

César Méndez is professor of Anthropology and head of research of Social Sciences at Universidad de Chile. His field-based archaeological research program, FONDECYT 1130128, is focused on human climate interactions in western Patagonia.

Michelle de Saint Pierre is professor of Anthropology at Universidad de Chile. Her main area of studies is the reconstruction of the biological history of aboriginal Amerindian populations through mitochondrial DNA.

Eugenio Aspillaga is professor of Anthropology and head of the Anthropology Department at Universidad de Chile. His main area is focused on bioarchaeological analyses of human remains, including studying ancient lifeways and paleopathologies.

Gustavo Politis is professor of Anthropology at Universidad Nacional del Centro de la Provincia de Buenos Aires and Universidad de la Plata. His field-based archaeological research program is focused on the early peopling of the Pampean area. 